\title{
Effects of nitrogenous compounds and phosphorus on the growth of toxic and non-toxic strains of Microcystis during cyanobacterial blooms
}

\author{
Timothy W. Davis ${ }^{1,3}$, Matthew J. Harke ${ }^{1}$, M. Alejandra Marcoval ${ }^{1}$, Jennifer Goleski ${ }^{1}$, \\ Celia Orano-Dawson ${ }^{2}$, Dianna L. Berry ${ }^{1}$, Christopher J. Gobler ${ }^{1, *}$ \\ ${ }^{1}$ Stony Brook University, School of Marine and Atmospheric Sciences, Stony Brook, New York 11794-5000, USA \\ ${ }^{2}$ Maryland Department of Natural Resources, Annapolis, Maryland 21401, USA \\ ${ }^{3}$ Present address: Australian Rivers Institute, Griffith University, Nathan, Queensland 4111, Australia
}

\begin{abstract}
Since the mid-twentieth century, both nutrient delivery rates and the frequency of harmful algal blooms (HABs) in coastal aquatic ecosystems have intensified. Recent studies have shown that nitrogen $(\mathrm{N})$ or phosphorus $(\mathrm{P})$ can limit primary production in freshwater systems, and Microcystis is able to utilize both inorganic and organic forms of $\mathrm{N}$. The present study quantified the microcystin synthetase gene $(m c y D)$ and the ribosomal RNA gene (16S) to assess how various nutrient sources affected the growth of toxic and non-toxic strains of Microcystis during natural blooms. During the present study, dense Microcystis blooms $\left(>10^{6}\right.$ cell equivalents $\mathrm{l}^{-1}$ ) were observed within 2 contrasting ecosystems in the eastern USA: a tidal tributary and a eutrophic lake. In both systems, all Microcystis populations were stimulated by N more frequently than P during nutrient amendment experiments. The abundance of toxic strains of Microcystis was enhanced by nutrient enrichment more frequently ( $83 \%$ of experiments) than non-toxic strains ( $58 \%$ of experiments), suggesting that toxic strains may have a greater demand for both nutrients. Furthermore, abundances of toxic strains of Microcystis were enhanced by inorganic $\mathrm{N}$ more frequently (67\% of experiments) than organic $\mathrm{N}$ ( $8 \%$ of experiments), while non-toxic strains were stimulated by organic $\mathrm{N}$ (50\% of experiments) more frequently than inorganic N ( $25 \%$ of experiments). Inorganic P increased abundances of toxic strains of Microcystis more frequently than non-toxic strains (42 and $33 \%$ of experiments, respectively). Therefore, the dominance of toxic Microcystis may be influenced by both the concentration and species of nutrients, with higher concentrations of inorganic $\mathrm{N}$ and/or P likely promoting blooms dominated by toxic strains and potentially yielding higher microcystin concentrations.
\end{abstract}

KEY WORDS: Microcystis - Toxic · Non-toxic · Nitrogen · Phosphorus · Inorganic · Organic · $m c y D$

Resale or republication not permitted without written consent of the publisher

\section{INTRODUCTION}

Harmful algal blooms (HABs) are a significant threat to fisheries, public health, and economies around the world. There are strong links between increased nutrient loading and HABs (Anderson et al. 2008, Heisler et al. 2008), particularly within freshwater ecosystems (Paerl 1988, Paerl et al. 2001). Traditionally, rates of primary production in freshwater ecosystems have been thought to be limited by phosphorus $(\mathrm{P} ;$ Schindler 1977 ,
Smith 1983, Hecky \& Kilham 1988), and increases in Ploading (mainly due to anthropogenic influences) have often been associated with blooms of cyanobacteria within these systems (Likens 1972, Paerl 1988). This paradigm is partly based on the assumption that diazotrophic cyanobacteria such as Anabaena and Aphanizomenon will dominate P-enriched systems that are depleted in nitrogenous nutrients (Paerl 1982, 1988).

Nitrogen $(\mathrm{N})$ may also play an important role in the occurrence of freshwater cyanobacteria blooms, par- 
ticularly for non-diazotrophic cyanobacteria such as Microcystis. Laboratory studies have demonstrated that higher $\mathrm{N}$ concentrations enhance the growth and toxicity of non-diazotrophic cyanobacteria such as Microcystis and Oscillatoria (Watanabe \& Oishi 1985, Codd \& Poon 1988, Utkilen \& Gjølme 1995, Orr \& Jones 1998). Some freshwater systems that have either large external P supplies or are shallow and have strong benthic mobilization of $\mathrm{P}$ from sediments can host levels of dissolved $\mathrm{N}$ that limit primary production (Vollenweider \& Kerekes 1982, Paerl 2009). Finally, recent field studies have demonstrated that N-loading can promote Microcystis blooms (Gobler et al. 2007, Moisander et al. 2009a).

Many cyanobacteria (both diazotrophic and nondiazotrophic) are able to utilize both organic and inorganic forms of $\mathrm{N}$ (Paerl 1988). Studies examining ${ }^{15} \mathrm{~N}$ assimilation by cyanobacterial blooms have observed uptake rates were highest for ammonium, followed by urea, then nitrate, suggesting that reduced forms of $\mathrm{N}$ may promote cyanobacterial blooms (Takamura et al. 1987, Mitamura et al. 1995, Présing et al. 2008). Furthermore, a recent study conducted by Dai et al. (2009) found that a toxic clone of Microcystis aeruginosa was able to take up and utilize amino acids, such as alanine, leucine, and arginine, to support growth and toxin production. Overall, these previous studies suggest both organic and inorganic $\mathrm{N}$ can be important in promoting blooms of cyanobacteria.

Bloom populations of Microcystis are comprised of toxic and non-toxic strains, which are distinguishable only via quantification of the microcystin synthetase gene (mcyA-J; Kurmayer \& Kutzenberger 2003, RintaKanto et al. 2005, Davis et al. 2009). Previous laboratory studies have found that non-toxic strains of Microcystis and Anabaena require lower nutrient concentrations to achieve maximal growth rates compared to toxic strains (Rapala et al. 1997, Vézie et al. 2002). Further, laboratory research suggests toxic strains of Microcystis are able to outgrow non-toxic strains at high inorganic N concentrations (Vézie et al. 2002). While the role of nutrients in the growth of total Microcystis populations in culture and in the field has been studied (Watanabe \& Oishi 1985, Codd \& Poon 1988, Blomqvist et al. 1994, Fujimoto et al. 1997, Orr \& Jones 1998, Baldia et al. 2007, Gobler et al. 2007, Moisander et al. 2009a), the manner in which nutrients may promote toxic and non-toxic strains of Microcysits within an ecosystem setting is unknown.

The aim of the present study was to investigate the role of various forms of organic and inorganic nitrogenous compounds, as well as orthophosphate, in the growth of toxic and non-toxic strains of Microcystis during natural bloom events. The dynamics of Microcystis blooms and nutrients in a lake and a tidal tribu- tary were monitored. Concurrently, nutrient amendment experiments were conducted to investigate how organic and inorganic $\mathrm{N}$ as well as orthophophate affected the dominance of toxic and non-toxic strains of Microcystis. This combined observational and experimental approach allowed for a robust assessment of how different forms of $\mathrm{N}$ and $\mathrm{P}$ may promote toxic Microcystis blooms. To our knowledge, this is the first study to specifically quantify the differential responses of toxic and non-toxic strains of Microcystis to nutrients during bloom events.

\section{MATERIALS AND METHODS}

Sampling-site and water-quality monitoring. During the present study, 2 hydrodynamically different ecosystems were studied in 2008. The Transquaking River ( $\mathrm{TR}_{i} 38^{\circ} 30^{\prime} 45^{\prime} \mathrm{N}_{;} 75^{\circ} 58^{\prime} 7^{\prime} \mathrm{W}$ ) is a flowing tributary that empties into the Chesapeake Bay. It spans $37 \mathrm{~km}$ along Maryland's (USA) eastern shore, and has previously been host to annual toxic cyanobacterial blooms (Tango \& Butler 2008). The seasonal rainfall (May to September) for this system during 2008 was, higher during May and June (14 and $11 \mathrm{~cm}$, respectively) when compared to July through September (11 cm total). Lake Agawam (LA) is a small $\left(0.5 \mathrm{~km}^{2}\right)$, shallow (4 m maximum depth), closed eutrophic system on Long Island, New York (USA; $40^{\circ} 52^{\prime} 05^{\prime \prime} \mathrm{N}_{\text {; }}$ $\left.72^{\circ} 25^{\prime} 96^{\prime \prime} \mathrm{W}\right)$ that often experiences dense and toxic cyanobacterial blooms (Gobler et al. 2007). In 2008, rainfall near LA was light in May and October (5.5 and $3.2 \mathrm{~cm}$, respectively) and higher from June through September $\left(13 \pm 3.7 \mathrm{~cm} \mathrm{mo}^{-1}\right)$. Both systems had similar levels of light transmission (mean Secchi depths = $0.6 \pm 0.1 \mathrm{~m}$ ). During 2008, LA and TR were sampled biweekly to monthly before, during, and after cyanobacterial blooms (May to November). At each site, surface temperature, dissolved oxygen, and $\mathrm{pH}$ were measured using a YSI 556 sonde. Twenty liters of surface water was collected in acid-cleaned carboys and taken to the laboratories where triplicate extracted chlorophyll $a$ and in vivo phycocyanin (as a proxy for total cyanobacteria) were measured with Turner Designs fluorometers using standard techniques (Parsons et al. 1984, Watras \& Baker 1988, Lee et al. 1994). For microcystin analysis, whole water was filtered onto triplicate $47 \mathrm{~mm}$ glass fiber filters $(\mathrm{GF} / \mathrm{F})$ and stored at $-20^{\circ} \mathrm{C}$ until analysis. Duplicate whole water samples were preserved with Lugol's iodine solution (5\% final concentration) to characterize and quantify the phytoplankton assemblage. For molecular analysis of Microcystis, water was filtered onto triplicate $2 \mu \mathrm{m}$ polycarbonate filters and immediately placed in CTAB (cetyl trimethylammonium bromide) lysis buffer. The 
samples were heated at $50^{\circ} \mathrm{C}$ for $10 \mathrm{~min}$, then flash frozen in liquid nitrogen, and stored at $-80^{\circ} \mathrm{C}$ until analysis. Triplicate dissolved nutrient samples were collected by filtering lake water through combusted $\mathrm{GF} / \mathrm{F}$ glass fiber filters and stored at $-20^{\circ} \mathrm{C}$ until analysis. All nutrient analyses were conducted using wet chemistry methods. Nitrate was analyzed by reducing the nitrate to nitrite using spongy cadmium as per Jones (1984). Ammonium, phosphate, and silicate were analyzed according to Parsons et al. (1984). Urea was analyzed following Price \& Harrison (1987). Dissolved free amino acids (DFAA) were measured in duplicate by high performance liquid chromatography (HPLC) (Lindroth \& Mopper 1979, Cowie \& Hedges 1992). Total dissolved nitrogen and phosphorus (TDN and TDP, respectively) were analyzed using persulfate digestion (Valderrama 1981). Dissolved organic $N$ and $\mathrm{P}$ (DON and DOP) were determined by subtracting DIN (dissolved inorganic $\mathrm{N}=$ nitrate, nitrite, and ammonium) from TDN and by subtracting DIP (orthophosphate) from TDP, respectively. The degree to which individual biological and environmental variables were correlated was evaluated by a Pearson's correlation matrix.

Impacts of inorganic and organic nitrogen on toxic and non-toxic Microcystis. Experiments were conducted to assess the impact of increased organic and inorganic $\mathrm{N}$ or orthophosphate concentrations on toxic and non-toxic Microcystis populations in TR and LA. Sets of triplicate, 11 bottles $(n=21)$ were filled with surface water from each experimental site and were either left unamended to serve as a control, or amended with various forms of $\mathrm{N}$ : $20 \mu \mathrm{M}$ nitrate $\left(\mathrm{NO}_{3}{ }^{-}\right), 20 \mu \mathrm{M}$ ammonium $\left(\mathrm{NH}_{4}{ }^{+}\right), 10 \mu \mathrm{M}(=20 \mu \mathrm{M} \mathrm{N})$ urea, $10 \mu \mathrm{M}(=20 \mu \mathrm{M} \mathrm{N})$, L-glutamine (GA), P $(1.25 \mu \mathrm{M}$ orthophosphate), or a combined treatment of $\mathrm{NO}_{3}{ }^{-}$and P. For the experiments conducted in LA, the bottles were placed in Old Fort Pond at the Stony BrookSouthampton marine station located $\sim 1 \mathrm{~km}$ west of Lake Agawam. For the experiments conducted in TR, experimental bottles were placed in an incubator (REVCO) with light and temperature levels matching conditions in TR. Light intensity and temperatures during experiments were measured every minute with in situ loggers (Onset Computer Corporation) and indicated that incubation temperatures and light levels remained within the same range as those found in each ecosystem. All bottles were gently inverted every 6 to $8 \mathrm{~h}$. After $48 \mathrm{~h}$, samples were filtered as described above to quantify chlorophyll a concentrations and densities of total, toxic, and non-toxic Microcystis via molecular methods. Using the molecular techniques described below, the densities of total and toxic Microcystis in each experimental bottle were quantified and the densities of non-toxic Microcystis were determined by difference, providing triplicate densities for each population within each treatment. For the 4 communities measured (total phytoplankton, total Microcystis, toxic Microcystis, and non-toxic Microcystis) differences in abundances among nutrient treatments were compared by means of 1-way ANOVAs or non-parametric Kruskal-Wallis tests, and differences among individual treatments were subsequently assessed with post hoc Tukey multiple comparison tests. For all results the standard variance presented is \pm 1 standard error (SE).

Microscopic analysis. Densities of Microcystis and other co-occurring cyanobacteria were quantified using gridded Sedgewick-Rafter counting chambers. For all samples, at least 200 cells, colonies, chains, or trichomes were enumerated. Microcystis, Anabaena, and Aphanizomenon were enumerated to the colony, chain, or trichome level, respectively. For eukaryotic plankton such as diatoms, dinoflagellates, and chlorophytes, cells were enumerated. This approach provided good reproducibility $(<15 \%$ relative standard deviation) among samples.

Microcystin analysis. Filters for microcystin analyses were extracted in $50 \%$ methanol containing $1 \%$ acetic acid using ultrasound (four $20 \mathrm{~s}$ bursts with a $20 \mathrm{~s}$ pause between bursts). Previous work has demonstrated that this extraction protocol provides $>90 \%$ recovery of microcystin-LR from glass fiber filters (Boyer et al. 2004). Following extraction, the methanolic extract was stored at $-80^{\circ} \mathrm{C}$ until analysis. Before analysis, the microcystin extract was diluted to $5 \%$ methanol and buffered to a pH of 7 using a $5 \%$ TrisEDTA buffer solution. Microcystin concentrations were measured using a microcystin enzyme-linked immunosorbent assay (Abraxis LLC) following the methodologies of Fischer et al. (2001). This assay is congener-independent as it is sensitive to the ADDA moiety that is found in almost all microcystins. These analyses yielded a detection limit of $0.10 \mu \mathrm{g} \mathrm{l}^{-1}$, a relative standard deviation of $10 \pm 1 \%$ for replicated environmental samples, and $99.5 \pm 8.2 \%$ recovery from environmental samples spiked with $5 \mu \mathrm{g} \mathrm{l^{-1 }}$ microcystin-LR, a concentration within the range of samples collected during the present study.

Molecular analyses. Total cellular nucleic acids were extracted from field and experimental samples using methods described in Coyne et al. (2001). Filtered environmental or experimental samples were submersed in CTAB buffer (Dempster et al. 1999) and supplemented with $20 \mu \mathrm{g} \mathrm{l^{-1 }}$ pGEM-3z(f+) plasmid (Promega Corporation), which served as an internal control for extraction efficiency and PCR inhibition (Coyne et al. 2005). The filters were then flash frozen using liquid nitrogen and stored at $-80^{\circ} \mathrm{C}$ until extraction. Nucleic acids were extracted after an initial heat- 
ing step at $65^{\circ} \mathrm{C}$, followed by a double chloroform extraction, and an isopropanol precipitation. Extracted nucleic acids were resuspended in $20 \mu \mathrm{l}$ of LoTE $\left(3 \mathrm{mmol} \mathrm{l}^{-1}\right.$ Tris-HCl [pH 8.0], $0.2 \mathrm{mmol} \mathrm{l}^{-1}$ EDTA [pH 8.0]). The quantity and quality of nucleic acids were assessed with a NanoDrop 1000 UV spectrophotometer (NanoDrop Technologies).

Two Microcystis-specific genetic targets were used during the present study, the Microcystis 16S rRNA gene (Microcystis 16S rDNA) and mcyD gene. The Microcystis 16S rRNA gene is specific to the Microcystis genus and permitted quantification of the abundance of the total Microcystis population. The mcyD gene is found within the microcystin synethtase gene operon, which is responsible for the production of microcystin and is only found in toxic strains of Microcystis (Tillett et al. 2000), thus allowing us to quantify the toxic population of Microcystis (Davis et al. 2009). The non-toxic population was calculated as the difference between the total and toxic population. Quantitative PCR (qPCR) was carried out using an ABI 7300 Real Time PCR instrument using TaqMan labeled probes (Applied Biosystems) and Microcystis-specific mcyD and 16S rDNA primers (Table 1). Each $10 \mu \mathrm{l}$ reaction included $5 \mu$ l of $2 \times$ TaqMan Master Mix (Applied Biosystems), $10 \mu \mathrm{M}$ of each primer (Integrated DNA Technologies), $10 \mu \mathrm{M}$ TaqMan probe (Table 1), and $1 \mu \mathrm{l}$ of a 1:25 dilution of the unknown DNA or standard. For amplification of the pGEM and 16S targets, the cycling conditions were $95^{\circ} \mathrm{C}$ for $10 \mathrm{~min}$, followed by 55 cycles of $95^{\circ} \mathrm{C}$ for $15 \mathrm{~s}$ and $60^{\circ} \mathrm{C}$ for $1 \mathrm{~min}$. For the mcyD gene, the cycling conditions were $95^{\circ} \mathrm{C}$ for $10 \mathrm{~min}$, followed by 55 cycles of $95^{\circ} \mathrm{C}$ for $15 \mathrm{~s}$, followed by $50^{\circ} \mathrm{C}$ for $1 \mathrm{~min}$, then $60^{\circ} \mathrm{C}$ for $1 \mathrm{~min}$. To prepare standard samples, cultured toxic Microcystis aeruginosa, Clone LE-3 (Rinta-Kanto et al. 2005), was enumerated by standard microscopy and collected on polycarbonate filters that were prepared and extracted as described above for field samples. A standard curve of dilutions of the extracted LE-3 genomic DNA was run with each analytical run to serve as a reference for numbers of total and toxic Microcystis cells. Such analyses indicate the number of $16 \mathrm{~S}$ rDNA and $m c y D$ genes per LE-3 cell and were not statistically different. Since some Microcystis cells may carry varying copies of the $16 \mathrm{~S}$ rDNA and mcyD genes, data were expressed as 'cell equivalents' rather than cell number (Rinta-Kanto et al. 2005). The numbers of toxic and total Microcystis cells were determined using the $\Delta \Delta \mathrm{CT}$ method (Livak \& Schmittgen 2001, Coyne et al. 2005). The difference between the number of mcyD cell equivalents (toxic cells) and 16S rDNA cell equivalents (total cells) represented the number of non-toxic cell equivalents (Rinta-Kanto et al. 2005).

Molecular quantification of Microcystis has been used in multiple field studies to date (e.g. Rinta-Kanto et al. 2005, Oberholster et al. 2006, Rinta-Kanto \& Wilhelm 2006, Hotto et al. 2008, Davis et al. 2009, Ha et al. 2009, Moisander et al. 2009a,b, Rinta-Kanto et al. 2009a,b, Ye et al. 2009, Baxa et al. 2010). Despite the increasingly common use of this method, there are fundamental differences between it and traditional cell counts that could create deviances between cell equivalents and traditional microscopic counts. Traditional microscopic counts can underestimate total Microcystis densities. Individual Microcystis cells range between 4 and $6 \mu \mathrm{m}$ in diameter, and in wild field populations both individual cells and colonies are present. However, it is not possible to distinguish between individual Microcystis cells and small phytoplankton in natural bloom samples using light microscopy. In contrast, our molecular method quantified all Microcystis cells caught on a $2 \mu \mathrm{m}$ filter. Furthermore, there can be multiple gene copies per cyanobacterium cell, which could also lead to differences between molecular

Table 1. Primers (Integrated DNA Technologies) and probes (Applied Biosystems) used in the qPCR analysis. F: forward primer; R: reverse primer; FAM: 6-Carboxyfluorescein; BHQ-1: Black Hole Quencher-1 (quenching range 480 to $580 \mathrm{~nm}$ )

\begin{tabular}{|c|c|c|c|}
\hline DNA target & Primer & Sequence $\left(5^{\prime}-3^{\prime}\right)$ & Source \\
\hline \multirow[t]{3}{*}{ pGEM plasmid DNA } & M13F & CCCAGTCACGACGTTGTAAAAACG & Coyne et al. (2005) \\
\hline & pGEMR & TGTGTGGAATTGTGAGCGGA & Coyne et al. (2005) \\
\hline & pGEM probe & $\begin{array}{l}\text { (Taq) FAM-CACTATAGAATACTCAAGCTTGCAT } \\
\text { GCCTGCA-BHQ-1 }\end{array}$ & Coyne et al. (2005) \\
\hline \multirow[t]{3}{*}{ Microcystis 16S rDNA } & $184 \mathrm{~F}$ & GCCGCRAGGTGAAAMCTAA & Neilan et al. (1997) \\
\hline & $431 \mathrm{R}$ & AATCCAAARACCTTCCTCCC & Neilan et al. (1997) \\
\hline & Probe & $\begin{array}{l}\text { (Taq) FAM-AAGAGCTTGCGTCTGATTAGCTAGT- } \\
\text { BHQ-1 }\end{array}$ & Rinta-Kanto et al. (2005) \\
\hline \multirow[t]{3}{*}{ Microcystis mcyD } & F2 & GGTTCGCCTGGTCAAAGTAA & Kaebernick et al. (2000) \\
\hline & $\mathrm{R} 2$ & CCTCGCTAAAGAAGGGTTGA & Kaebernick et al. (2000) \\
\hline & Probe & $\begin{array}{l}\text { (Taq) FAM-ATGCTCTAATGCAGCAACGGCAAA- } \\
\text { BHQ-1 }\end{array}$ & Rinta-Kanto et al. (2005) \\
\hline
\end{tabular}


quantification and microscopic counts. Importantly, we have consistently obtained identical cell densities of the toxic Microcystis clone LE-3 when quantified via light microscopy or qPCR with the $16 \mathrm{~S}$ or mcyD gene markers (T. W. Davis et al. unpubl. data). Furthermore, prior studies (Davis et al. 2009) have found that toxic (mcyD-containing) Microcystis cells are consistently (4 ecosystems, multiple years) correlated with microcystin concentrations, whereas non-mcyD-containing cell equivalents are not correlated with toxin levels, suggesting that this method accurately enumerates toxic and non-toxic Microcystis populations.

\section{RESULTS}

\section{Transquaking River cyanobacteria blooms}

In 2008, TR hosted dense cyanobacterial blooms co-dominated by Microcystis and Aphanizomenon (Table 2). Peak algal and cyanobacterial densities occurred on 10 June, while peak Microcystis densities, as measured by the $16 \mathrm{~S}$ rRNA gene $(3.1 \pm 0.63 \times$ $10^{8}$ cell equivalents $\mathrm{l}^{-1}$ ) occurred on 24 June (Fig. 1). Within the total Microcystis population, toxic strains dominated from late May through early July with peak densities of $2.8 \pm 0.23 \times 10^{8}$ cell equivalents $\mathrm{l}^{-1}$, representing $62 \pm 20 \%$ of the total Microcystis population (Fig. 1). After mid-July, dominance shifted towards non-toxic strains of Microcystis, which achieved peak densities of $3.6 \pm 0.13 \times 10^{7}$ cell equivalents $\mathrm{l}^{-1}$ in late August (Fig. 1). Microcystis colonies in TR on average
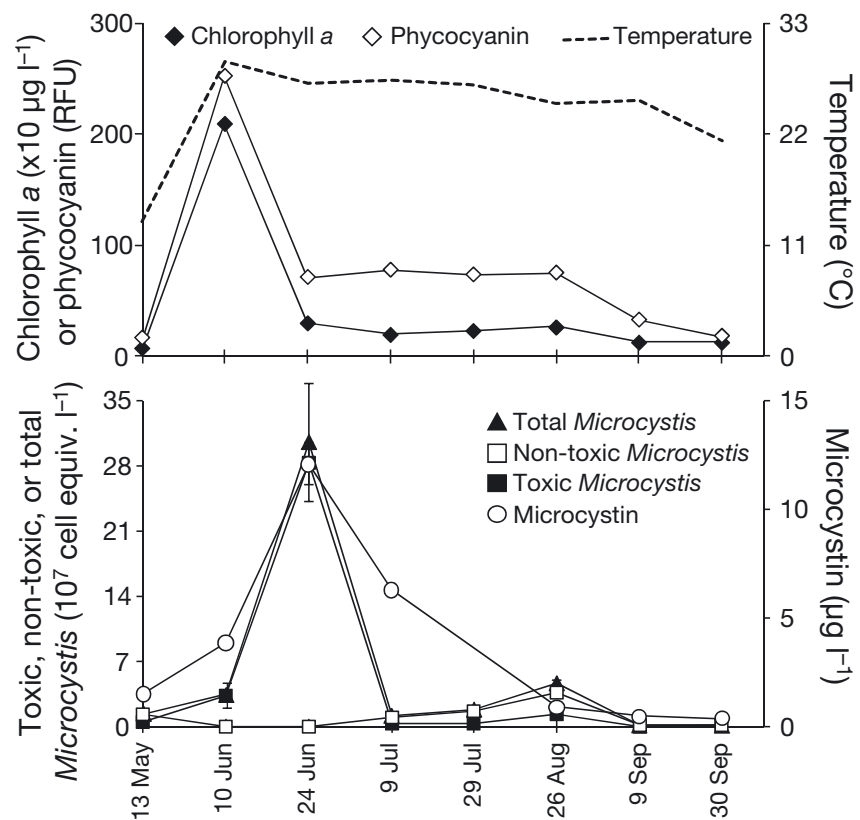

Fig. 1. Time series of parameters measured in the Transquaking River in 2008. Upper panel: levels of total chl $a$, phycocyanin, and temperature. Lower panel: densities of total, nontoxic, and toxic Microcystis, as well as concentrations of microcystin. Error bars represent $\pm 1 \mathrm{SE}$ of replicated samples

comprised $47 \pm 19$ cells. Microcystin concentrations ranged from 0.36 to $12.1 \mathrm{\mu g} \mathrm{l}^{-1}$ and peaked in unison with toxic Microcystis densities on 24 June (Fig. 1). Microcystin concentrations were significantly correlated with toxic Microcystis densities $(\mathrm{p}<0.01)$, but not

Table 2. Mean autotrophic plankton densities (SE in parentheses) as quantified via light microscopy for the Transquaking River and Lake Agawam in 2008. Counts are in colonies, chains, and trichomes per milliliter for Microcystis, Anabaena, and Aphanizomenon, respectively, and in cells per milliliter for the other groups

\begin{tabular}{|lcccccc|}
\hline Sampling date & Microcystis & Anabaena & Aphanizomenon & Diatoms & Chlorophytes & Dinoflagellates \\
\hline Transquaking River & & & & & & \\
13 May & $325(25)$ & $0(0)$ & $0(0)$ & $1100(25)$ & $125(30)$ & $0(0)$ \\
10 Jun & $400(27)$ & $35000(110)$ & $0(0)$ & $130(9)$ & $0(0)$ & $210(80)$ \\
24 Jun & $4900(100)$ & $700(100)$ & $51000(2800)$ & $2600(220)$ & $1100(100)$ & $3000(180)$ \\
9 Jul & $7350(250)$ & $125(125)$ & $120000(7100)$ & $16000(1100)$ & $3900(580)$ & $125(130)$ \\
29 Jul & $4800(80)$ & $15(15)$ & $20000(1400)$ & $1400(10)$ & $990(50)$ & $210(70)$ \\
26 Aug & $11000(95)$ & $240(30)$ & $21000(600)$ & $1500(55)$ & $15(15)$ & $100(10)$ \\
9 Sep & $3300(24)$ & $845(12)$ & $44000(1100)$ & $2800(12)$ & $4800(210)$ & $155(10)$ \\
30 Sep & $1000(45)$ & $0(0)$ & $24000(182)$ & $1600(68)$ & $3000(50)$ & $95(5)$ \\
Lake Agawam & & & & & \\
3 Jun & $952(95)$ & $0(0)$ & $0(0)$ & $200(20)$ & $540(50)$ & $0(0)$ \\
5 Jun & $1420(142)$ & $0(0)$ & $0(0)$ & $170(20)$ & $250(30)$ & $0(0)$ \\
1 Jul & $813(81)$ & $27(3)$ & $13(1)$ & $180(20)$ & $160(0)$ & $0(0)$ \\
23 Jul & $1300(130)$ & $380(38)$ & $820(82)$ & $0(0)$ & $40(4)$ & $0(0)$ \\
18 Aug & $1800(180)$ & $0(0)$ & $30(30$ & $890(90)$ & $20(2)$ & $0(0)$ \\
23 Sep & $5000(500)$ & $47(5)$ & $0(8)$ & $170(20)$ & $27(3)$ & $0(0)$ \\
15 Oct & $4000(400)$ & $67(7)$ & $220(22)$ & $290(30)$ & $40(40)$ & $0(0)$ \\
30 Oct & $4900(490)$ & $67)$ & & \\
\hline
\end{tabular}


non-toxic Microcystis densities, chlorophyll $a$, phycocyanin, or the total cyanobacterial densities $(p>0.05)$. Concentrations of inorganic nitrogen were highest during May and June $(>1 \mu \mathrm{M})$, but dropped to $<1 \mu \mathrm{M}$ during the summer and early fall (Table 2), while DIN:DIP ratios were chronically low $(3.2 \pm 1.8)$. Silicate levels were high in TR $(25 \pm 8.3 \mu \mathrm{M})$, while urea and DFAA concentrations were quite low $(0.3 \pm 0.1$ and 0.1 $\pm 0.01 \mu \mathrm{M}$, respectively). DON was the largest aqueous $\mathrm{N}$ pool, with concentrations ranging from $14.1 \pm 6.59$ to $44.8 \pm 1.85 \mu \mathrm{M}$ (Table 3), while DOP concentrations ranged from 0.4 to $1.4 \mu \mathrm{M}$ (Table 3). Non-toxic strains of Microcystis were significantly correlated with DON concentrations from June through October $(p<0.01)$. Temperatures in TR rose from $13.4^{\circ} \mathrm{C}$ in May to $29.2^{\circ} \mathrm{C}$ in July and dropped to $21.4^{\circ} \mathrm{C}$ by October (Fig. 1).

\section{Lake Agawam cyanobacteria blooms}

LA hosted cyanobacterial blooms that differed from those in TR in community composition and intensity (Table 2, Fig. 2). The LA blooms were dominated by Microcystis on every date sampled (Table 2). Total Microcystis densities ranged from $1.59 \pm 0.09$ to $17.3 \pm$ $0.10 \times 10^{6}$ cell equivalents $\mathrm{l}^{-1}$, with peak densities occurring on 15 October (Fig. 2). Unlike TR, the total Microcystis community was dominated by non-toxic strains throughout the 2008 field season $(83 \pm 4 \%$ of total Microcystis cells; Fig. 2). Non-toxic strains of Microcystis ranged from $1.42 \pm 0.06$ to $15.3 \pm 0.06 \times 10^{6}$ cell equivalents $1^{-1}$ (Fig. 2), while toxic Microcystis strains ranged from $0.7 \pm 0.3$ to $2.81 \pm 0.20 \times 10^{6}$ cell equivalents $\mathrm{l}^{-1}$, with peak densities occurring on

Table 3. Mean dissolved inorganic and organic nutrient concentrations ( $\mu \mathrm{M}$ with SE in parentheses) for the Transquaking River and Lake Agawam, 2008. DIN: dissolved inorganic nitrogen; DIP: dissolved inorganic phosphate; DON: dissolved organic nitrogen; DOP: dissolved organic phosphorus; DFAA: dissolved free amino acids

\begin{tabular}{|c|c|c|c|c|c|c|}
\hline \multirow{2}{*}{ Sampling date } & \multirow[b]{2}{*}{ Nitrate } & \multirow[b]{2}{*}{ Ammonium } & \multirow{2}{*}{$\begin{array}{l}\text { norganic nutrients } \\
\text { Silicate }\end{array}$} & & \multirow{2}{*}{\multicolumn{2}{|c|}{ DIP }} \\
\hline & & & & DIN & & \\
\hline \multicolumn{7}{|c|}{ Transquaking River } \\
\hline 13 May & $10.25(0)$ & $6.36(0.13)$ & $16.0(3.28)$ & $16.6(0.23)$ & \multicolumn{2}{|c|}{$3.87(0.38)$} \\
\hline $10 \mathrm{Jun}$ & $1.99(0.68)$ & $3.56(0.02)$ & $1.23(0.04)$ & $3.77(0.35)$ & \multicolumn{2}{|c|}{$2.92(0.39)$} \\
\hline 24 Jun & $0.08(0.02)$ & $0.84(0.13)$ & $48.5(7.21)$ & $0.92(0.12)$ & \multicolumn{2}{|c|}{$1.09(0.06)$} \\
\hline $9 \mathrm{Jul}$ & $0.17(0.10)$ & $0.74(0.07)$ & $71.6(3.02)$ & $0.91(0.06)$ & \multicolumn{2}{|c|}{$0.97(0.08)$} \\
\hline $29 \mathrm{Jul}$ & $0.07(0.02)$ & $0.57(0.03)$ & $11.9(0.27)$ & $0.65(0.04)$ & \multicolumn{2}{|c|}{$0.63(0.05)$} \\
\hline 26 Aug & $0.30(0.16)$ & $0.62(0.02)$ & $10.0(1.07)$ & $0.91(0.17)$ & \multicolumn{2}{|c|}{$0.37(0.04)$} \\
\hline 9 Sep & $0.59(0.03)$ & $0.57(0.03)$ & $27.6(4.99)$ & $0.82(0.23)$ & \multicolumn{2}{|c|}{$0.41(0.05)$} \\
\hline 30 Sep & $0.26(0.08)$ & $0.57(0.08)$ & $15.8(0.03)$ & $0.69(0.20)$ & \multicolumn{2}{|c|}{$0.39(0.01)$} \\
\hline \multicolumn{7}{|l|}{ Lake Agawam } \\
\hline 5 Jun & $5.48(0.13)$ & $2.45(0.28)$ & $22.6(0.01)$ & $7.94(0.34)$ & \multicolumn{2}{|c|}{$0.06(0.00)$} \\
\hline $1 \mathrm{Jul}$ & $1.18(0.08)$ & $3.44(0.77)$ & $20.7(1.23)$ & $4.62(0.70)$ & \multicolumn{2}{|c|}{$0.38(0.05)$} \\
\hline $23 \mathrm{Jul}$ & $1.25(0.03)$ & $1.23(0.15)$ & $45.9(10.7)$ & $2.06(0.57)$ & \multicolumn{2}{|c|}{$0.12(0.01)$} \\
\hline 18 Aug & $0.43(0.25)$ & $0.48(0.01)$ & $59.4(2.79)$ & $0.78(0.33)$ & \multicolumn{2}{|c|}{$0.30(0.08)$} \\
\hline $23 \mathrm{Sep}$ & $4.14(0.12)$ & $0.47(0.04)$ & $68.5(1.30)$ & $4.61(0.15)$ & \multicolumn{2}{|c|}{$0.21(0.10)$} \\
\hline 15 Oct & $6.85(0.14)$ & $0.68(0.04)$ & $68.1(5.80)$ & $7.53(0.14)$ & \multicolumn{2}{|c|}{$0.18(0.02)$} \\
\hline \multirow[t]{2}{*}{ Sampling date } & \multicolumn{4}{|c|}{ - Organic nutrients - } & \multicolumn{2}{|c|}{ Ratios } \\
\hline & Urea & DFAA & DON & DOP & DIN:DIP & DON:DOP \\
\hline \multicolumn{7}{|c|}{ Transquaking River } \\
\hline 13 May & $0.38(0.02)$ & $0.1(0.002)$ & $14.1(6.59)$ & $0.61(0.06)$ & 4 & 23 \\
\hline $10 \mathrm{Jun}$ & $0.42(0.01)$ & $0.28(0.005)$ & $19.4(1.78)$ & $1.06(0.05)$ & 1 & 18 \\
\hline 24 Jun & $0.45(0.01)$ & $0.1(0.002)$ & $24.1(1.44)$ & $1.05(0.16)$ & 1 & 23 \\
\hline $9 \mathrm{Jul}$ & $0.31(0.01)$ & $0.06(0.002)$ & $28.5(2.82)$ & $0.86(0.27)$ & 1 & 33 \\
\hline $29 \mathrm{Jul}$ & $0.38(0.09)$ & $0.07(0.002)$ & $21.9(0.99)$ & $0.31(0.06)$ & 1 & 71 \\
\hline 26 Aug & $0.13(0.02)$ & $0.09(0.006)$ & $44.8(1.85)$ & $0.56(0.10)$ & 2 & 79 \\
\hline 9 Sep & $0.27(0.05)$ & $0.05(0.002)$ & $24.6(1.71)$ & $0.47(0.09)$ & 2 & 52 \\
\hline 30 Sep & $0.14(0.08)$ & 0.07 (0.002) & 23.9 (6.69) & $0.55(0.25)$ & 2 & 43 \\
\hline \multicolumn{7}{|l|}{ Lake Agawam } \\
\hline 5 Jun & $0.06(0.06)$ & $0.13(0.003)$ & $17.0(8.27)$ & $1.09(0.37)$ & 262 & 16 \\
\hline $1 \mathrm{Jul}$ & $0.05(0.02)$ & $0.18(0.01)$ & $13.4(2.81)$ & $0.68(0.13)$ & 12 & 20 \\
\hline $23 \mathrm{Jul}$ & $0.04(0.00)$ & $0.10(0.003)$ & $14.0(2.66)$ & $1.15(0.10)$ & 17 & 12 \\
\hline 18 Aug & $0.06(0.04)$ & $0.05(0.002)$ & $7.94(0.78)$ & $0.60(0.06)$ & 3 & 13 \\
\hline $23 \mathrm{Sep}$ & $0.35(0.02)$ & $0.09(0.002)$ & $12.6(1.59)$ & $0.72(0.23)$ & 22 & 17 \\
\hline 15 Oct & $0.26(0.14)$ & $0.11(0.003)$ & 4.91 (1.15) & $0.97(0.29)$ & 42 & 5 \\
\hline
\end{tabular}




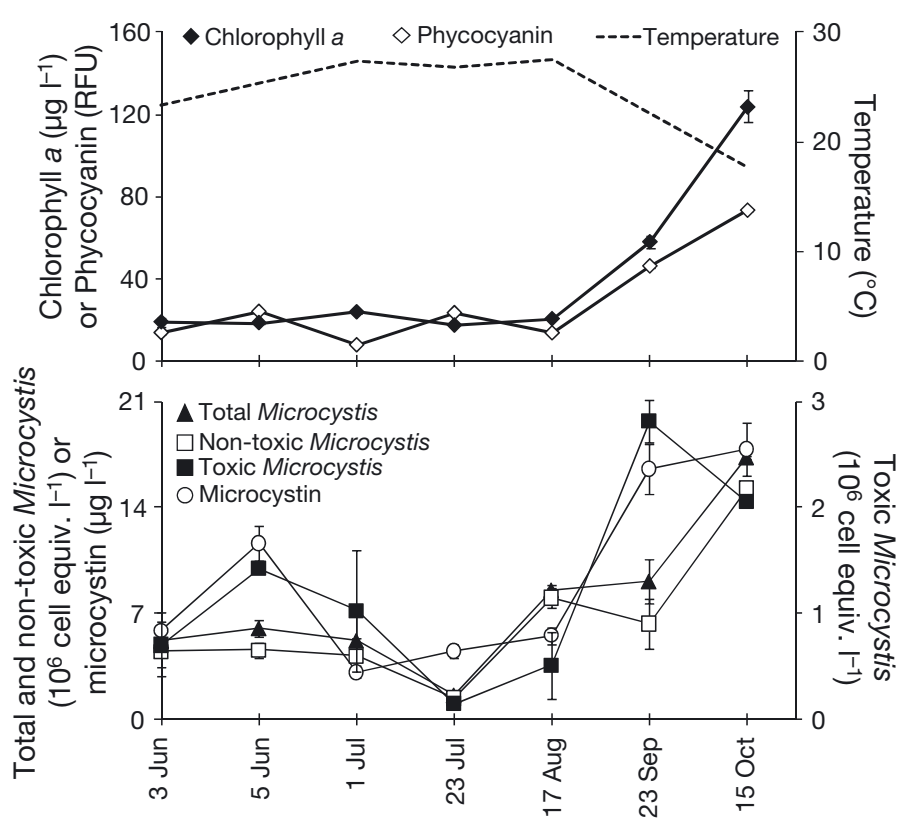

Fig. 2. Time series of parameters measured in Lake Agawam in 2008. Further details as in Fig. 1

23 September (Fig. 2). Microcystis colonies in LA on average comprised $65 \pm 9$ cells. As was the case in TR, microcystin concentrations (3.1 to $17.8 \mu \mathrm{g} \mathrm{l}^{-1}$ ) were significantly correlated with toxic Microcystis cell equivalents ( $\mathrm{p}<0.01$ ), but not with total or non-toxic Microcystis cell equivalents ( $p>0.05)$. DIN concentrations in LA were high in the early summer ( 4 to $7 \mu \mathrm{M}$ ), lower in July and August $(<2 \mu \mathrm{M})$, and elevated again in the fall (4 to $7 \mu \mathrm{M}_{i}$ Table 3 ). In contrast, silicate levels were always high (20 to $70 \mu \mathrm{M}$ ) in LA (Table 3), while DIP, urea, and DFAA were always low $(<0.4,0.1$, and $0.1 \mu \mathrm{M}$, respectively; Table 3$)$. DON and DOP were the largest dissolved $\mathrm{N}$ and $\mathrm{P}$ pools in LA, with mean concentrations of $10 \pm 2$ and $1.2 \pm 0.2 \mu \mathrm{M}$ (Table 3 ). Temperatures in LA rose from $23.3^{\circ} \mathrm{C}$ in June to $27.5^{\circ} \mathrm{C}$ in August and dropped to $10.3^{\circ} \mathrm{C}$ by the end of October (Fig. 2).

\section{Growth responses of toxic and non-toxic strains of Microcystis during nutrient amendment experiments}

Transquaking River

Biomass of the total phytoplankton community in TR was significantly increased by one form of $\mathrm{N}$ in every experiment conducted and was most consistently stimulated by nitrate ( $p<0.05$; Table 4$)$. Similarly, the total Microcystis population in TR was stimulated by $\mathrm{N}$ through most of the field season (5 of 6 experiments; $\mathrm{p}<0.05$; Table 4, Fig. 3). Interestingly, the total Microcystis community was more frequently stimulated by urea $(50 \%$ of experiments) than by nitrate $(33 \%$ of experiments), and was never stimulated by ammonium ( $\mathrm{p}<0.05$; Table 4; Fig. 3). GA also stimulated the total Microcystis population in a third of the experiments conducted, doubling cell equivalents above the control in the final 2 experiments ( $p<0.05$; Table 4, Fig. 3). Increased phosphate concentrations yielded significantly increased Microcystis cell equivalents in 2 experiments conducted in June and early July ( $\mathrm{p}<$ 0.05; Table 4, Fig. 3).

Toxic strains of Microcystis were stimulated more often by $\mathrm{N}$ enrichment (83\% of experiments) than their

Table 4. Treatments that significantly stimulated the total cyanobacterial community, total Microcystis community, non-toxic Microcystis, and toxic Microcystis relative to control treatments $(p<0.05)$ during nutrient amendment experiments in the Transquaking River and Lake Agawam in 2008. $\mathrm{NO}_{3}$ : nitrate; $\mathrm{NH}_{4}$ : ammonium; $\mathrm{N}+\mathrm{P}$ : nitrate and orthophosphate; P: orthophosphate; U: urea; GA: L-glutamine. A dash indicates no treatment significantly increased the population over the control

\begin{tabular}{|c|c|c|c|c|}
\hline Sampling date & Total phytoplankton & Total Microcystis & Non-toxic Microcystis & Toxic Microcystis \\
\hline \multicolumn{5}{|c|}{ Transquaking River } \\
\hline 10 Jun & $\mathrm{NO}_{3}$ & $\mathrm{NO}_{3}, \mathrm{U}, \mathrm{P}$ & - & $\mathrm{NO}_{3}, \mathrm{U}, \mathrm{P}$ \\
\hline 24 Jun & $\mathrm{N}+\mathrm{P}$ & - & $\mathrm{U}, \mathrm{GA}, \mathrm{N}+\mathrm{P}$ & $\mathrm{NO}_{3}, \mathrm{NH}_{4}$ \\
\hline $9 \mathrm{Jul}$ & $\mathrm{NO}_{3}, \mathrm{~N}+\mathrm{P}$ & $\mathrm{NO}_{3}, \mathrm{P}$ & $e^{-1}$ & $\mathrm{NO}_{3}, \mathrm{P}$ \\
\hline $29 \mathrm{Jul}$ & $\mathrm{NO}_{3}, \mathrm{NH}_{4}, \mathrm{U}, \mathrm{GA}$ & $\mathrm{P}, \mathrm{N}+\mathrm{P}$ & $\mathrm{P}$ & $\mathrm{NO}_{3}, \mathrm{NH}_{4}, \mathrm{~N}+\mathrm{P}$ \\
\hline 26 Aug & $\mathrm{NO}_{3}, \mathrm{NH}_{4}, \mathrm{U}, \mathrm{GA}, \mathrm{N}+\mathrm{P}$ & U, GA & $\mathrm{U}, \mathrm{GA}$ & - \\
\hline 9 Sep & $\mathrm{NO}_{3}, \mathrm{GA}, \mathrm{N}+\mathrm{P}$ & $\mathrm{U}, \mathrm{GA}, \mathrm{N}+\mathrm{P}$ & $\mathrm{U}, \mathrm{GA}$ & $\mathrm{N}+\mathrm{P}$ \\
\hline \multicolumn{5}{|l|}{ Lake Agawam } \\
\hline 5 Jun & - & - & - & $\mathrm{P}$ \\
\hline $1 \mathrm{Jul}$ & $\mathrm{NH}_{4}, \mathrm{P}, \mathrm{N}+\mathrm{P}$ & - & - & $\mathrm{NH}_{4}, \mathrm{P}, \mathrm{N}+\mathrm{P}$ \\
\hline $23 \mathrm{Jul}$ & $\mathrm{N}+\mathrm{P}$ & $\mathrm{NO}_{3}, \mathrm{NH}_{4}, \mathrm{U}, \mathrm{P}$ & $\mathrm{NO}_{3}, \mathrm{NH}_{4}, \mathrm{U}, \mathrm{P}$ & $\mathrm{NO}_{3}$ \\
\hline $18 \mathrm{Aug}$ & $\mathrm{NO}_{3}, \mathrm{U}, \mathrm{GA}, \mathrm{N}+\mathrm{P}$ & $\mathrm{NO}_{3}, \mathrm{U}, \mathrm{P}, \mathrm{N}+\mathrm{P}$ & $\mathrm{NO}_{3}, \mathrm{U}, \mathrm{P}, \mathrm{N}+\mathrm{P}$ & - \\
\hline $23 \mathrm{Sep}$ & $\mathrm{N}+\mathrm{P}$ & 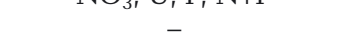 & 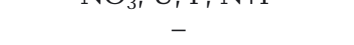 & $\mathrm{NO}_{3}, \mathrm{NH}_{4}$ \\
\hline 15 Oct & - & $\mathrm{NO}_{3}, \mathrm{NH}_{4}, \mathrm{U}, \mathrm{GA}, \mathrm{P}, \mathrm{N}+\mathrm{P}$ & $\mathrm{NO}_{3}, \mathrm{NH}_{4}, \mathrm{U}, \mathrm{GA}, \mathrm{P}, \mathrm{N}+\mathrm{P}$ & $\mathrm{NO}_{3}, \mathrm{NH}_{4}, \mathrm{P}$ \\
\hline
\end{tabular}



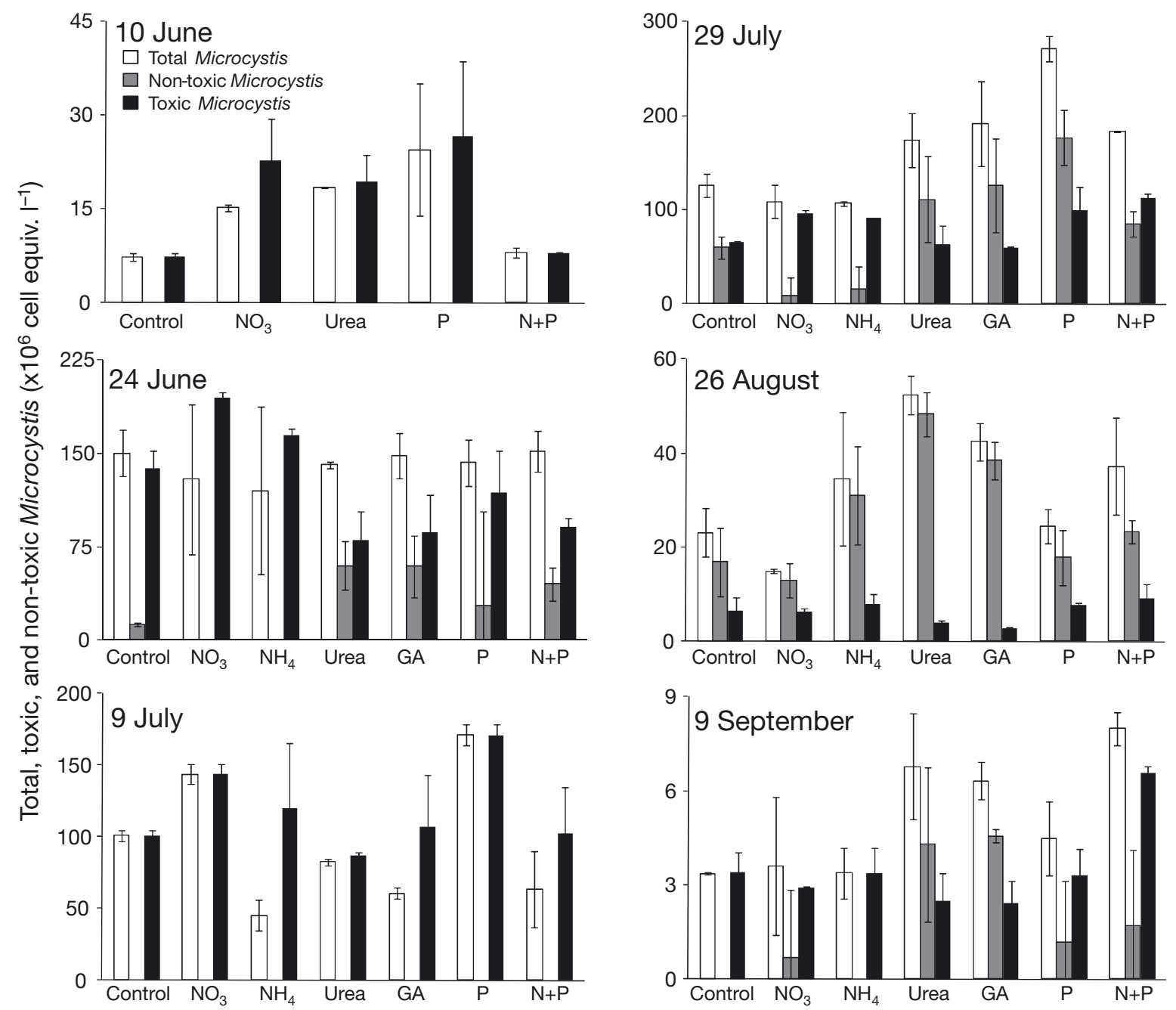

Fig. 3. Total, non-toxic, and toxic Microcystis densities during nutrient amendment experiments conducted in the Transquaking River during the summer of 2008. Error bars represent $\pm 1 \mathrm{SE}$ of triplicate experimental bottles. $\mathrm{NO}_{3}$ : nitrate; P: orthophosphate; $\mathrm{N}+\mathrm{P}$ : nitrate and orthophosphate; $\mathrm{NH}_{4}$ : ammonium; GA: L-glutamine. During several experiments and treatments, the non-toxic Microcystis population was below methodological detection limits

non-toxic counterparts $(66 \%$ of experiments; $\mathrm{p}<0.05$; Table 4, Fig. 3). Toxic strains were stimulated by inorganic forms of $\mathrm{N}$ during most experiments (83\%), increasing cell equivalents from 1 to 4 times above the control ( $\mathrm{p}<0.05$; Table 4, Fig. 3). In contrast, cell equivalents of toxic strains were enhanced by urea in only 1 experiment, but were never affected by GA (Table 4, Fig. 3). P additions yielded increased toxic Microcystis in one-third of the all TR experiments, increasing cell equivalents, on average, 2 -fold beyond the control ( $\mathrm{p}<0.05$; Table 4, Fig. 3). Finally, on 2 dates (29 July and 9 September), the combined addition of $\mathrm{N}$ and $\mathrm{P}$ stimulated toxic Microcystis populations ( $\mathrm{p}<$ 0.05; Table 4, Fig. 3). In a manner nearly the opposite of toxic strains, non-toxic strains of Microcystis were never significantly affected by the addition of any indi- vidual inorganic $\mathrm{N}$ compound ( $\mathrm{p}>0.05$; Table 4, Fig. 3). These strains were stimulated, however, by organic N compounds (urea and GA) during half of the experiments, displaying cell equivalents between 2 and 6 times higher than the control $(\mathrm{p}<0.05$; Table 4 , Fig. 3). Finally, non-toxic strains were significantly enhanced above the control by $\mathrm{P}$ in 1 experiment and by the dual addition of $\mathrm{N}$ and $\mathrm{P}$ in another experiment ( $<<0.05$; Table 4, Fig. 3).

\section{Lake Agawam}

None of the phytoplankton populations monitored were limited by any form of $\mathrm{N}$ in LA in June (Table 4, Fig. 4). From early July to late September, the total 

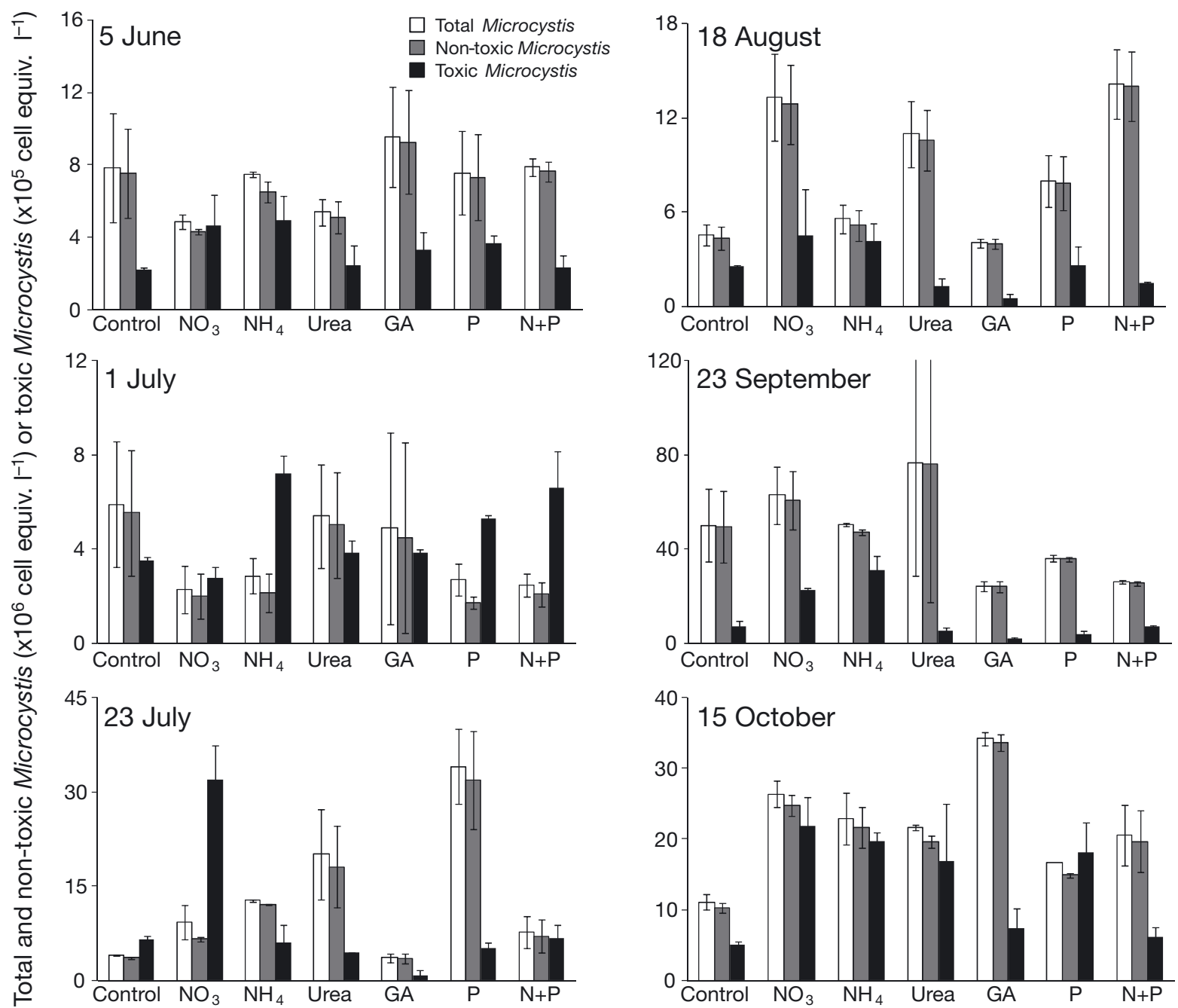

Fig. 4. Total, non-toxic, and toxic Microcystis densities during nutrient amendment experiments conducted in Lake Agawam during the summer of 2008. Note that the scale for the toxic cells is 1 order of magnitude less than that of the total and non-toxic cell scale. Error bars represent $\pm 1 \mathrm{SE}$ of triplicate experimental bottles. $\mathrm{NO}_{3}$ : nitrate; $\mathrm{NH}_{4}$ : ammonium; GA: L-glutamine; P: orthophosphate; $\mathrm{N}+\mathrm{P}$ : nitrate and orthophosphate

phytoplankton community was stimulated by both inorganic and organic forms of $\mathrm{N}(\mathrm{p}<0.05$; Table 4$)$. Since the non-toxic strains of Microcystis comprised most $(84 \%)$ of the total Microcystis community in LA, their growth responses to nutrients were generally the same as those in the total Microcystis population. The densities of the total and non-toxic Microcystis cells were not affected by nutrients until late July, when both inorganic and organic $\mathrm{N}$ additions yielded densities significantly higher than the control treatment $(\mathrm{p}<$ 0.05; Table 4, Fig. 4). In a manner similar to TR, the total Microcystis and non-toxic populations were stimulated by urea and nitrate more frequently than ammonium, displaying cell equivalents 2 to 5 times beyond the control ( $p<0.05$; Table 4, Fig. 4 ). The addition of $\mathrm{P}$ significantly enhanced total and non-toxic
Microcystis abundances in half of the experiments conducted, increasing densities 2 to 9 times above the control ( $\mathrm{p}<0.05$; Table 4, Fig. 4).

The response of toxic strains of Microcystis to nutrient enrichment differed from that of other algal populations. The abundance of toxic Microcystis cell equivalents was significantly enhanced by nutrient enrichment over the controls $(p<0.05)$ more frequently (83\% of experiments) than that of the non-toxic population (50\% of experiments; Table 4, Fig. 4). Unlike their non-toxic counterparts, toxic Microcystis in LA was enhanced only by inorganic forms of $\mathrm{N}$, with nitrate and ammonium yielding densities that were between 2 to 5 times greater than that of the control $(\mathrm{p}<0.05$; Table 4, Fig. 4). Toxic Microcystis was also enhanced by $\mathrm{P}$ additions in half of the experiments, as 
P increased cell equivalents 2 to 4 times beyond those of the controls ( $\mathrm{p}<0.05$; Table 4, Fig. 4). Finally, on 1 date (1 July), the combined addition of $\mathrm{N}$ and $\mathrm{P}$ yielded toxic Microcystis densities 2 times above that of the control ( $\mathrm{p}<0.05$; Table 4, Fig. 4).

\section{DISCUSSION}

Eutrophication is considered a primary cause of many HABs (Paerl 1997, Anderson et al. 2008, Heisler et al. 2008), particularly within freshwater ecosystems (Paerl 1988, 2008, Paerl et al. 2001). Because freshwater ecosystems are traditionally viewed as P-limited, management plans for such systems are commonly aimed toward reducing $\mathrm{P}$ loads (Schindler et al. 2008). The present study provides new insight into the role of nutrients in the occurrence of toxic and non-toxic Microcystis blooms. Specifically, the findings demonstrate that $\mathrm{N}$ enrichment can promote blooms of Microcystis more frequently than $\mathrm{P}$ and that inorganic nutrients may favor toxic strains over those which cannot produce microcystin.

Microcystis community composition differed between the 2 ecosystems studied. Toxic strains of Microcystis dominated the TR community during the early summer months (May and June) before non-toxic strains became more abundant, whereas non-toxic strains dominated the LA Microcystis community (83 \pm $4 \%$ ) on every date sampled. The dominance of toxic strains in TR but not in LA could be related to the availability of P in each system. Vézie et al. (2002) reported that the growth rates of toxic Microcystis exceeded those of non-toxic strains under high $\mathrm{P}$ concentrations, and concentrations of $\mathrm{P}$ were nearly an order of magnitude higher in TR $(1.3 \mu \mathrm{M})$ compared to in LA $(0.19 \mu \mathrm{M} ; \mathrm{p}<0.05 ; t$-test $)$. Changes in the dominance of toxic strains throughout the year further implicated the importance of $\mathrm{P}$ for this population in TR, as P concentrations were significantly higher from May through mid-July $(2.2 \pm 0.71 \mu \mathrm{M})$, when toxic strains dominated the Microcystis population $(62 \pm 20 \%)$, than in late July through October $(0.45 \pm 0.06 \mu \mathrm{M}$; $\mathrm{p}<0.01$; $t$-test), when non-toxic strains were most abundant (77 $\pm 7 \%$; Table 3, Fig. 1). In addition, toxic Microcystis abundances were enhanced by $\mathrm{P}$ more frequently than non-toxic strains, a finding consistent with our prior work on lakes in the northeast United States (Davis et al. 2009). Oh et al. (2000) reported that Plimitation can enhance the levels of microcystin per cell in Microcystis. In contrast, we found significant $(p<0.05)$ linear co-variance between densities of toxic cells and concentrations of microcystin in each ecosystem studied, suggesting cellular microcystin content did not change substantially as P levels changed, per- haps in part because non-toxic Microcystis cells succeeded toxic cells when $P$ concentrations declined. The association of toxic Microcystis with high DIP and non-toxic strains with lower DIP may be due to several factors. Hesse et al. (2001) reported that a microcystinproducing Microcystis strain had a higher content of light-harvesting pigments than non-toxic mutant strains. Hence, the RNA and DNA required for the synthesis of both light-harvesting pigments and microcystin by toxic strains of Microcystis may represent a significant $\mathrm{P}$ requirement.

Toxic strains of Microcystis were stimulated by $\mathrm{N}$ enrichment more frequently than the non-toxic strains during the present study (Table 5). This difference was strongest in TR, where DIN concentrations and DIN: DIP ratios were lowest and $\mathrm{N}$ enrichment enhanced the abundance of toxic Microcystis in all but a single experiment, but did so for the non-toxic strains in only half of the experiments (Table 4, Fig. 4). The stronger response of toxic Microcystis to $\mathrm{N}$ is consistent with laboratory studies, which have reported that toxic strains of Microcystis and Anabaena require higher $\mathrm{N}$ concentrations to achieve maximal growth rates compared to non-toxic strains (Rapala et al. 1997, Vézie et al. 2002). Furthermore, laboratory experiments have established clear relationships between DIN supply and microcystin production by toxic strains of Microcystis (Orr \& Jones 1998, Long et al. 2001), which is consistent with the $\mathrm{N}$ requirements for microcystin synthesis, as microcystin is a N-rich compound (10 N atoms per molecule), and studies have found that microcystin can represent up to $2 \%$ of the cellular dry weight of Microcystis (Nagata et al. 1997). Beyond this $\mathrm{N}$ in the toxin, toxic Microcystis strains will have additional $\mathrm{N}$ requirements associated with the enzymes involved in the synthesis of microcystin (Tillett et al. 2000), as well as with additional light-harvesting pigments they may possess (Hesse et al. 2001). Although the precise mechanism is unclear, toxic Microcystis cells seem to have a higher $\mathrm{N}$ requirement than nontoxic cells (Rapala et al. 1997, Vézie et al. 2002, present study).

The species of $\mathrm{N}$ employed during field experiments strongly influenced whether toxic or non-toxic strains dominated Microcystis populations. For example, in every experiment where toxic strains of Microcystis were stimulated by individual $\mathrm{N}$ compounds $(\mathrm{n}=8)$, they were always stimulated by at least 1 form of inorganic N (Table 4). On the other hand, this population was enhanced by organic $\mathrm{N}$ in only 1 experiment (Table 4). Conversely, when non-toxic strains were stimulated by individual $\mathrm{N}$ forms $(\mathrm{n}=6)$, this happened more frequently via organic $\mathrm{N}$ compounds $(\mathrm{n}=6)$ than inorganic $\mathrm{N}$ compounds ( $\mathrm{n}=2$; Tables 4 \& 5). These findings are consistent with the results of Vézie et al. 
Table 5. The percentage of experiments in which $\mathrm{N}$ compounds significantly increased the density of the total phytoplankton community, total Microcystis community, non-toxic Microcystis, and toxic Microcystis relative to control treatments ( $<<0.05)$ during nutrient amendment experiments. Percentages and number of significant treatments out of total number of experiments (in parentheses) shown

\begin{tabular}{|lccrr|}
\hline \multirow{2}{*}{ Compound } & \multicolumn{4}{c|}{} \\
\cline { 2 - 4 } & Total phytoplankton & Total Microcystis & Non-toxic Microcystis & Toxic Microcystis \\
\hline Any N compound & $83(10 / 12)$ & $67(8 / 12)$ & $50(6 / 12)$ & $75(9 / 12)$ \\
Nitrate & $50(6 / 12)$ & $42(5 / 12)$ & $25(3 / 12)$ & $58(7 / 12)$ \\
Ammonium & $25(3 / 12)$ & $17(2 / 12)$ & $17(2 / 12)$ & $42(5 / 12)$ \\
Inorganic N & $58(7 / 12)$ & $42(5 / 12)$ & $25(3 / 12)$ & $67(8 / 12)$ \\
Urea & $25(3 / 12)$ & $50(6 / 12)$ & $30(6 / 12)$ & $8(1 / 12)$ \\
L-glutamine & $33(4 / 12)$ & $25(3 / 12)$ & $50(6 / 12)$ & $0(0 / 12)$ \\
Organic N & $33(4 / 12)$ & $50(6 / 12)$ & $33(4 / 12)$ & $8(1 / 12)$ \\
Orthophosphate & $8(1 / 12)$ & $50(6 / 12)$ & & $42(5 / 12)$ \\
\hline
\end{tabular}

(2002), who found that increases in nitrate concentrations yielded faster growth rates for toxic Microcystis cultures compared to non-toxic cultures. While the biochemical mechanism(s) responsible for these trends are unclear, there was a clear differentiation regarding the response of toxic and non-toxic Microcystis populations to organic and inorganic $\mathrm{N}$ during the present study.

For both study sites, all Microcystis populations were more frequently enhanced by $\mathrm{N}$ enrichment than by $\mathrm{P}$ enrichment, indicating that, in both systems, these populations were more $\mathrm{N}$ - than P-limited (Tables 4 \& 5). This finding is contrary to the long held view that freshwater ecosystems are exclusively P-limited (Schindler 1977, Smith 1983, Hecky \& Kilham 1988, Schindler et al. 2008), but consistent with more recent laboratory (Vézie et al. 2002) and field (Gobler et al. 2007, Moisander et al. 2009a) studies of Microcystis. Importantly, during all of the experiments conducted across both sites, $\mathrm{N}$ or $\mathrm{P}$ increased the abundance of 1 or more of the Microcystis populations relative to control treatments, and there were 3 occasions at each site when increases in $\mathrm{N}$ and $\mathrm{P}$ concentrations did so, suggesting these populations were occasionally co-limited by $\mathrm{N}$ and $\mathrm{P}$ (Table 4, Figs. 3 \& 4). As such, the dual management of $\mathrm{N}$ and $\mathrm{P}$ will be required to control the future occurrence of toxic Microcystis blooms in these, and likely other, systems (Howarth \& Paerl 2008, Lewis \& Wurtsbaugh 2008, Conley et al. 2009, Paerl 2009, Xu et al. 2010).

The differing responses of toxic and non-toxic strains of Microcystis during $\mathrm{N}$ and $\mathrm{P}$ enrichment, and our observations of these populations and nutrients in TR, provide evidence for a hypothesis that may partly account for the seasonal dynamics of these strains in temperate ecosystems. In TR, we observed a seasonal transition from higher inorganic nutrients, lower organic (DON, DOP, urea, DFAA) nutrients (Table 3), and dominance by toxic Microcystis strains during early summer (May to July; Fig. 1), followed by a depletion of inorganic nutrients, an elevation in organic nitrogen, and dominance by non-toxic Microcystis in late summer (Table 3, Fig. 1). This pattern of nutrients is common for aquatic ecosystems, as warming summer temperatures bring decreases in freshwaterbased nutrient delivery rates (Gobler \& Sañudo-Wilhelmy 2001) and increases in phytoplankton nutrient assimilation rates (Goldman \& Carpenter 1974). Thus, while toxic Microcystis thrives on the abundant sources of inorganic nutrients during early summer, the depletion of these nutrients by mid-summer, potentially due to the decreased rainfall and/or groundwater flow, likely contributes to the demise of this population, a pattern observed in TR. The remineralization of dead cells and higher pelagic and benthic remineralization rates within warmer summer waters (Boynton et al. 1995) both likely contribute towards a water column that is enriched in DON during late summer. The present study demonstrated that non-toxic strains of Microcystis experience increased growth rates after enrichment with organic compounds, which could partially account for their dominance during late summer in TR. This population shift between toxic and non-toxic strains concurrent with decreases in DIN has been found in other systems, such as Lake Ronkonkoma, New York (Davis et al. 2009). Furthermore, Briand et al. (2009) found a similar seasonal shift in genotypes from toxic strains to non-toxic strains in a French reservoir. This trend was not seen in LA possibly due to the low $\mathrm{P}$ (mean = $0.19 \mu \mathrm{M}$ DIP) concentrations, which may have inhibited toxic strains from becoming dominant within this system due to their high $P$ requirement (Vézie et al. 2002); toxic strains are always a minor component of the total Microcystis community in this system (Davis et al. 2009, present study).

In conclusion, Microcystis populations in LA and TR were frequently stimulated by $\mathrm{N}$ and, to a lesser 
extent, P. Toxic strains of Microcystis were more frequently promoted by $\mathrm{N}$ than non-toxic strains, but non-toxic strains were more frequently stimulated by organic $\mathrm{N}$ than toxic strains were. Therefore, dominance of toxic Microcystis and, ultimately, the toxicity of Microcystis blooms may be influenced by both the concentration and species of available nutrients, with increases in inorganic $\mathrm{N}$ - and/or P-loading likely promoting blooms dominated by toxic strains and potentially yielding higher microcystin concentrations.

Acknowledgements. This research was supported by a grant from the US EPA-ECOHAB program \#R83-3220. We thank Peter Tango, Walter Butler, and Mary Price for field and laboratory support in Maryland. We thank Charles Wall, Amanda Burson, and Lindsay Koza Moore for field and laboratory assistance. We thank Drs Greg Boyer, Nicholas Fisher, Jackie Collier, Darcy Lonsdale, and 3 anonymous reviewers for helpful comments on earlier drafts of this manuscript. The Stony Brook-Southampton Marine Science Center provided logistical support.

\section{LITERATURE CITED}

Anderson DM, Burkholder JM, Cochlan WP, Glibert PM and others (2008) Harmful algal blooms and eutrophication: examples of linkages from selected coastal regions of the United States. Harmful Algae 8:39-53

Baldia SF, Evangelista AD, Aralar EV, Santiago AE (2007) Nitrogen and phosphorus utilization in the cyanobacterium Microcystis aeruginosa isolated from Laguna de Bay, Philippines. J Appl Phycol 19:607-613

Baxa DV, Kurobe T, Ger KA, Lehman PW, The SJ (2010) Estimating the abundance of toxic Microcystis in the San Francisco Estuary using quantitative real-time PCR. Harmful Algae 9:342-349

Blomqvist P, Pettersson A, Hyenstrand P (1994) Ammoniumnitrogen: a key regulatory factor causing dominance of non-nitrogen-fixing cyanobacteria in aquatic systems. Arch Hydrobiol 132:141-164

Boyer GL, Matzin MC, Shambaugh AD, Satchwell MF, Rosen $\mathrm{BH}$, Mihuc $\mathrm{T}$ (2004) The occurrence of cyanobacterial toxins in Lake Champlain. In: Manley T (ed) Partnerships and research in the new millennium. Kluwer Academic/ Plenum Publishers, New York, NY

Boynton WR, Garber JH, Summers R, Kemp WM (1995) Inputs, transformations, and transport of nitrogen and phosphorus in Chesapeake Bay and selected tributaries. Estuaries 18:285-314

Briand E, Escoffier N, Straub C, Sabart M, Quibler C, Humbert JF (2009) Spatiotemporal changes in the genetic diversity of a bloom-forming Microcystis aeruginosa (cyanobacteria) population. ISME J 3:419-429

Codd GA, Poon GK (1988) Cyanobacterial toxins. In: Rogers LJ, Gallon JR (eds) Biochemistry of the algae and cyanobacteria. Clarendon Press, Oxford

Conley DJ, Paerl HW, Howarth RW, Boesch DF and others (2009) Controlling eutrophication by reducing both nitrogen and phosphorus. Science 323:1014-1015

Cowie GL, Hedges JI (1992) Improved amino acid quantification in environmental samples: charged-matched recov- ery standards and reduced analysis time. Mar Chem 37: $223-238$

Coyne KJ, Hutchins DA, Hare CE, Cary SC (2001) Assessing temporal and spatial variability in Pfiesteria piscicida distributions using molecular probing techniques. Aquat Microb Ecol 24:275-285

Coyne KJ, Handy SM, Demir E, Whereat EB and others (2005) Improved quantitative real-time PCR assays for enumeration of harmful algal species in field samples using an exogenous DNA reference standard. Limnol Oceanogr Methods 3:381-391

Dai R, Liu H, Qu J, Zhao X, Hou Y (2009) Effects of amino acids on microcystin production of the Microcystis aeruginosa. J Hazard Mater 161:730-736

> Davis TW, Berry DL, Boyer GL, Gobler CJ (2009) The effects of temperature and nutrients on the growth and dynamics of toxic and non-toxic strains of Microcystis during cyanobacteria blooms. Harmful Algae 8:715-725

Dempster EL, Pryor KV, Francis D, Young JE, Rogers HJ (1999) Rapid DNA extraction from ferns for PCR-based analyses. Biotechniques 27:66-68

Fischer WJ, Garthwaite I, Miles CO, Ross KM and others (2001) Congener-independent immunoassay for microcystins and nodularins. Environ Sci Technol 35:4849-4856

$>$ Fujimoto N, Sudo R, Sugiura N, Inamori Y (1997) Nutrientlimited growth of Microcystis aeruginosa and Phormidium tenue and competition under various N:P supply ratios and temperature. Limnol Oceanogr 42:250-256

> Gobler CJ, Sañudo-Wilhelmy SA (2001) Temporal variability of groundwater seepage and brown tide blooms in a Long Island embayment. Mar Ecol Prog Ser 217:299-309

Gobler CJ, Davis TW, Coyne KJ, Boyer GL (2007) The interactive influences of nutrient loading and zooplankton grazing on the growth and toxicity of cyanobacteria blooms in a eutrophic lake. Harmful Algae 6:119-133

> Goldman JC, Carpenter EJ (1974) A kinetic approach to the effect of temperature on algal growth. Limnol Oceanogr 19:756-766

> Ha JH, Hidaka T, Tsuno H (2009) Quantification of toxic Microcystis and evaluation of its dominance ratio in blooms using real-time PCR. Environ Sci Technol 43: 812-818

- Hecky RE, Kilham P (1988) Nutrient limitation of phytoplankton in freshwater and marine environments. Limnol Oceanogr 33:796-822

> Heisler JP, Gilbert J, Burkholder J, Anderson D and others (2008) Eutrophication and harmful algal blooms: a scientific consensus. Harmful Algae 8:3-13

Hesse K, Dittmann E, Börner T (2001) Consequences of impaired microcystin production for light-dependent growth and pigmentation of Microcystis aeruginosa PCC 7806. FEMS Microbiol Ecol 37:39-43

Hotto AM, Satchwell MF, Berry DL, Gobler CJ, Boyer GL (2008) Spatial and temporal diversity of microcystins and microcystin-producing genotypes in Oneida Lake, NY. Harmful Algae 7:671-681

Howarth R, Paerl HW (2008) Coastal marine eutrophication: control of both nitrogen and phosphorus is necessary. Proc Natl Acad Sci USA Lett 105:E103

Jones MN (1984) Nitrate reduction by shaking with cadmium: alternative to cadmium colums. Water Res 18:643-646

> Kaebernick M, Neilan BA, Borner T, Dittmann E (2000) Light and the transcriptional response of the microcystin biosynthesis gene cluster. Appl Environ Microbiol 66: 3387-3392

Kurmayer R, Kutzenberger T (2003) Application of real time PCR for quantification of microcystin genotypes in a pop- 
ulation of the toxic cyanobacterium Microcystis sp. Appl Environ Microbiol 69:6723-6730

Lee T, Tsuzuki M, Takeuchi T, Yokoyama K, Karube I (1994) In vivo fluorometric method for early detection of cyanobacterial waterblooms. J Appl Phycol 6:489-495

Lewis WM Jr, Wurtsbaugh WA (2008) Control of lacustrine phytoplankton by nutrients: erosion of the phosphorus paradigm. Int Rev Hydrobiol 93:446-465

Likens GE (1972) Eutrophication and aquatic ecosystems. In: Nutrients and eutrophication: the limiting-nutrient controversy. Limnol Oceanogr (Spec Symp) 1:3-13

> Lindroth P, Mopper K (1979) High performance liquid chromatographic determination of subpicomole amounts of amino acids by precolumn fluorescence derivatization with ophthaldialdehyde. Anal Chem 51:1667-1674

> Livak KJ, Schmittgen TD (2001) Analysis of relative gene expression data using real-time quantitative PCR and the 2- $\Delta \Delta \mathrm{Ct}$ method. Methods 25:402-408

Long BM, Jones GJ, Orr PT (2001) Cellular microcystin content in N-limited Microcystis aeruginosa can be predicted from growth rate. Appl Environ Microbiol 67:278-283

Mitamura O, Saijo Y, Hino K, Barbosa FAR (1995) The significance of regenerated nitrogen for phytoplankton productivity in the Rio Doce Valley Lakes, Brazil. Arch Hydrobiol 134:179-194

Moisander PH, Ochiai M, Lincoff A (2009a) Nutrient limitation of Microcystis aeruginosa in northern California Klamath River reservoirs. Harmful Algae 8:889-897

Moisander PH, Lehman PW, Ochiai M, Corum S (2009b) Diversity of Microcystis aeruginosa in the Klamath River and San Fancisco Bay delta, California, USA. Aquat Microb Ecol 57:19-31

Nagata S, Tsutsumi T, Hasegawa A, Yoshida F, Ueno Y, Watanabe MF (1997) Enzyme immunoassay for the direct determination of microcystins in environmental water. J AOAC Int 80:408-417

> Neilan BA, Jacobs D, DelDot T, Blackall LL, Hawkins PR, Cox PT, Goodman AE (1997) rRNA sequences and evolutionary relationships among toxic and nontoxic cyanobacteria of the genus Microcystis. Int J Syst Bacteriol 47: 693-697

Oberholster PJ, Botha AM, Cloete TE (2006) Use of molecular markers as indicators for winter zooplankton grazing on toxic benthic cyanobacteria colonies in an urban Colorado lake. Harmful Algae 5:705-716

> Oh HM, Lee SJ, Jang MH, Yoon BD (2000) Microcystin production by Microcystis aeruginosa in a phosphoruslimited chemostat. Appl Environ Microbiol 66:176-179

Orr PT, Jones GJ (1998) Relationship between microcystin production and cell division rates in nitrogen-limited Microcystis aeruginosa cultures. Limnol Oceanogr 43: 1604-1614

Paerl HW (1982) Environmental factors promoting and regulating N-fixing blue-green algal blooms in the Chowan River. North Carolina Water Resour Res Inst Rep 176, University of North Carolina, Raleigh, NC

Paerl HW (1988) Nuisance phytoplankton blooms in coastal, estuarine, and inland waters. Limnol Oceanogr 33: 823-847

Paerl HW (1997) Coastal eutrophication and harmful algal blooms: importance of anthropogenic deposition and groundwater as 'new' nitrogen and other nitrogen sources. Limnol Oceanogr 42:1154-1165

Paerl HW (2008) Nutrient and other environmental controls of harmful cyanobacterial blooms along the freshwatermarine continuum. In: Hudnell $\mathrm{KH}$ (ed) Cyanobacterial harmful algal blooms: state of the science and research needs. Advances in experimental medicine and biology, Vol 619. Springer Publishing, New York, NY

Paerl HW (2009) Controlling eutrophication along the freshwater-marine continuum: dual nutrient ( $\mathrm{N}$ and $\mathrm{P}$ ) reductions are essential. Estuaries Coasts 32:593-601

Paerl HW, Fulton RS, Moisander PH, Dyble J (2001) Harmful freshwater algal blooms with an emphasis on cyanobacteria. TheScientificWorldJournal 1:76-113

Parsons TR, Maita Y, Lalli CM (1984) A manual of chemical and biological methods for seawater analysis. Pergamon Press, Oxford

Présing M, Preston T, Takátsy A, Spröber P and others (2008) Phytoplankton nitrogen demand and the significance of internal and external nitrogen sources in a large shallow lake (Lake Balaton, Hungary). Hydrobiologia 599:87-95

> Price NM, Harrison PJ (1987) Comparison of methods for the analysis of dissolved urea in seawater. Mar Biol 94: 307-317

Rapala J, Sivonen K, Lyra C, Niemela SI (1997) Variation of microcystins, cyanobacterial hepatotoxins, in Anabaena spp. as a function of growth stimulation. Appl Environ Microbiol 63:2206-2212

> Rinta-Kanto JM, Wilhelm SW (2006) Diversity of microcystinproducing cyanobacteria in spatially isolated regions of Lake Erie. Appl Environ Microbiol 72:5083-5085

Rinta-Kanto JM, Ouellette AJA, Boyer GL, Twiss MR, Bridgeman TB, Wilhelm SW (2005) Quantification of toxic Microcystis spp. during the 2003 and 2004 blooms in western Lake Erie using quantitative real-time PCR. Environ Sci Technol 39:4198-4205

Rinta-Kanto JM, Konopko EA, DeBruyn JM, Bourbonniere RA, Boyer GL, Wilhelm SW (2009a) Lake Erie Microcystis: relationship between microcystin production, dynamics of genotypes and environmental parameters in a large lake. Harmful Algae 8:665-673

> Rinta-Kanto JM, Saxton MA, DeBruyn JM, Smith JL and others (2009b) The diversity and distribution of toxigenic Microcystis spp. in present day and archived pelagic and sediment samples from Lake Erie. Harmful Algae 8: 385-394

> Schindler DW (1977) Evolution of phosphorus limitation in lakes. Science 195:260-262

Schindler DW, Hecky RE, Findlay DL, Stainton MP and others (2008) Eutrophication of lakes cannot be controlled by reducing nitrogen input: results of a 37-year wholeecosystem experiment. Proc Natl Acad Sci USA 105: $11254-11258$

> Smith VH (1983) Low nitrogen to phosphorus ratios favor dominance by blue-green algae in lake phytoplankton. Science 221:669-671

Takamura N, Iwakuma T, Yasuno M (1987) Uptake of ${ }^{13} \mathrm{C}$ and ${ }^{15} \mathrm{~N}$ (ammonium, nitrate, and urea) by Microcystis in Lake Kasumigaura. J Plankton Res 9:151-165

Tango PJ, Butler W (2008) Cyanotoxins in tidal waters of Chesapeake Bay. Northwest Nat 15:403-416

Tillett D, Dittmann E, Erhard M, von Dohren H, Borner T, Neilan BA (2000) Structural organization of microcystin biosynthesis in Microcystis aeruginosa PCC7806: an integrated peptide-polyketide synthetase system. Chem Biol 7:753-764

> Utkilen H, Gjølme N (1995) Iron-stimulated toxin production in Microcystis aeruginosa. Appl Environ Microbiol 61: 797-800

> Valderrama JC (1981) The simultaneous analysis of total N and total P in natural waters. Mar Chem 10:109-122

> Vézie C, Rapala J, Vaitomaa J, Seitsonen J, Sivonen K (2002) Effect of nitrogen and phosphorus on growth of toxic and 
nontoxic Microcystis strains and on intracellular microcystin concentrations. Microb Ecol 43:443-454

Vollenweider RA, Kerekes JJ (1982) Eutrophication of waters: monitoring, assessment, and control. OCED, Paris

> Watanabe MF, Oishi S (1985) Effects of environmental factors on toxicity of a cyanobacterium (Microcystis aeruginosa) under culture conditions. Appl Environ Microbiol 49: $1342-1344$

> Watras CJ, Baker AL (1988) Detection of planktonic cyano-

Editorial responsibility: Douglas Capone,

Los Angeles, California, USA bacteria by tandem in vivo fluorometry. Hydrobiologia 169:77-84

Xu H, Paerl HW, Qin B, Zhu G, Gao G (2010) Nitrogen and phosphorus inputs control phytoplankton growth in eutrophic Lake Taihu, China. Limnol Oceanogr 55: 420-432

Ye W, Liu X, Tan J, Li D, Yang H (2009) Diversity and dynamics of microcystin-producing cyanobacteria in China's third largest lake, Lake Taihu. Harmful Algae 8:637-644

Submitted: March 2, 2010; Accepted: August 7, 2010

Proofs received from author(s): October 7, 2010 